Бердичевська М. В. ORCID ID: 0000-0002-7191-4235

Національний технічний університет України «Київський політехнічний інститут імені Ігоря Сікорського»

\title{
СУЧАСНА КОНЦЕПЦІЯ ВДОСКОНАЛЕННЯ СИСТЕМ МЕНЕДЖМЕНТУ ЯКОСТІ НА ПРОМИСЛОВИХ ПІДПРИЕМСТВАХ В УМОВАХ ГЛОБАЛІЗАЦІЇ РИНКУ
}

\section{THE MODERN CONCEPT FOR IMPROVING OF QUALITY MANAGEMENT SYSTEM OF INDUSTRIAL ENTERPRISES UNDER GLOBALIZATION OF MARKETS}

Досліджуються існуючі підходи до вдосконалення систем менеджменту якості на вітчизняних промислових підприємствах в умовах глобалізачіi ринків. Викладено авторську точку зору про те, щз діюча на підприємствах система менеджменту якості $\epsilon$ динамічна «річ», яка тісно пов'язана з прочесами глобалізаџіï ринків і тому потребує постійного вдосконалення. Сформульовано головні напрями вдосконалення систем менеджменту якості на промислових підприємствах з урахуванням таких характеристик глобальних ринків, як насиченість, поінформованість покупців, мінливість динаміки. Доведено необхідність оновлення діючої бази державних стандартів та інших документів вітчизняної системи сертифікації УкрСЕПРО. Сформульовано чотири головних критеріїв конкурентоспроможності продукиії підприємств, які сьогодні відіграють вирішальну роль під час вибору товару (якість, собівартість, иіна, витрати в прочесі експлуатачіï, зручність сервісу, імідж виробника) , та які необхідно враховувати при вдосконаленні діючих систем менеджменту якості. Доведено, щуо стратегія, якій віддається перевага якості, че стратегія спрямована на довготривале та стале положення підприємства на глобальному ринку.Розроблено алгоритм комплексу робіт постійного удосконалення в системі менеджменту якості підприємств, який передбачає виконання ряду послідовних етапів, починаючи від встановлення причин вдосконалення прочесів та закінчуючи очінюванням досягнутих підприємством результатів від вдосконалення систем менеджменту якості.Сформульовано основні фундаментальні принципи, яких необхідно дотримуватись для удосконалення діючих систем менеджменту якості на вітчизняних промислових підприємствам. Доведено, щуо в сучасних умовах господарювання для вітчизняних промислових підприємств найбільш придатною для вдосконалення діючих систем менеджменту якості є концепція TQM (Total Quality Management) i сформульовано шість основних принципів, на яких вона базується (впровадження статистичних методів контролю якості та технологічних прочесів, впровадження конщепиіi «Just in time», бенчмаркінг тощо). Висвітлено практичне значення отриманих результатів.

Ключові слова: вдосконалення систем менеджменту якості, глобальні ринки, критерії конкурентоспроможності, концепція TQM (Total Quality Management)

The existing approaches for improving quality management systems on the industrial enterprises under markets globalization are explored in this article. The author's view on the enterprises' quality management system that is a dynamic "thing" which is connected to markets globalization processes, and therefore requires continuous improvement, is highlighted. The 
main directions of the improvement of quality management system so find us trial enterprises are defined looking at characteristics such as: saturation of markers, buyer awareness and variability of market dynamics.

The need to update the operating database of state standards and other documents of UkrSEPRO system is proved. The four main benchmarks of the competitiveness of enterprise products, which play a crucial role while choosing the product (quality, cost, price, costs in operation, convenience of service, manufacture's image), and which must be taken into account in improving the existing quality management systems are defined. It is proved the strategy, which is preferred to quality, is aimed at the long-term and steady state of the enterprise in the global market. The algorithm of the complex of continuous improvement works in the system of quality management on enterprises is developed, which involves the implementation of a series of successive stages, from the establishment of the reasons for the improvement to of processes and ending with the evaluation of the results achieved by the enterprise from the improvement of quality management systems. The basic fundamental principles that need to be followed to improve existing quality management systems at domestic industrial enterprises are formulated. It is proved the concept of TQM (Total Quality Management)is the most suitable for the improvement of existing quality management systems under present marketing conditions. The six basic principles (implementation of statistical quality control methods of technological processes, implementation of the concept «Just in time», benchmarking) on which TQM is based are defined. The practical significance of the obtained results is highlighted.

Keywords: quality management system improvement, global markets, competitiveness criteria, TQM (Total Quality Management) concept.

Вступ. В умовах глобалізації ринків діючі на вітчизняних підприємствах системи менеджменту якості не можуть залишатися осторонь. Адже системи менеджменту якості $\epsilon$ також динамічною категорією, які повинні повністю вдосконалюватися попри те, що на багатьох підприємствах, як свідчить практичний досвід, нехтують цим положенням i вважають кінцевим результатом факт отримання сертифікату відповідності на систему.

Проблеми систем менеджменту якості на сьогодні залишається предметом дослідження багатьох вітчизняних та зарубіжних науковців. Вирішенню проблеми системного управління якості присвячено роботи таких вітчизняних вчених, як Р. А. Бичківський, С. С. Гаркавенко, П. Я. Калита, М. І. Шаповал та ін. Вирішальний вплив на сучасну теорію i практику забезпечення якості мали роботи таких всесвітньовідомих спеціалістів, як Дж. Джуран, У. Шухарт, А. Фейгенбаум, Е. Демінг, К. Ісікава, Ф. Кросбі, Т. Тагуті та ін. Ці роботи лягли в основу професіональної концепції якості.

Попри велику кількість публікацій 3 питань якості, проблеми вдосконалення діючих на промислових підприємствах систем менеджменту якості залишається і досі дискусійним та невирішеним до кінця. Все це спонукає до подальшого дослідження у цій сфері.

Постановка завдання. Метою статті $\epsilon$ дослідження набутого вітчизняного та зарубіжного досвіду 3 питань функціонування систем менеджменту якості на промислових підприємствах в умовах глобалізації ринків. Для досягнення поставленої мети сформульовано наступні завдання: 
сформувати напрямки розвитку систем менеджменту якості на вітчизняних промислових підприємствах з урахуванням характеристик глобальних ринків (насиченість, мінливість, поінформованість покупців тощо); сформулювати критерії конкурентоспроможності продукції підприємств, які необхідно першочергово враховувати при вдосконаленні діючих на підприємствах системах менеджменту якості.

Методологія. Під час проведення дослідження використано системний підхід, а також методи аналізу та синтезу. Теоретико-методологічну основу дослідження становлять праці вітчизняних та зарубіжних вчених у сфері якості. Для досягнення мети дослідження було використано загальнонаукові та спеціальні методи: абстрактно-аналітичний - при визначенні суті вдосконалення систем менеджменту якості, графічний - для наочного відображення запропонованих положень дослідження.

Результати дослідження. Сучасний ринок, на якому товари переміщуються досить вільно, без суттєвих обмежень, отримав назву глобального ринку. Процес глобалізації підсилює створення таких економічних зон, як Європейське співтовариство. Проте глобальний ринок це не тільки назва, це поняття включає в себе такі характеристики, що принципово відрізняють його від світового ринку 30-40-річної давнини.

Наприкінці 1970-х років світовий ринок характеризували такі проблеми у сфері менеджменту якості:

- неухильне підвищення вимог з боку споживачів до відповідного рівня якості продукції, а також до забезпечення іiї стабільності;

- високі економічні ризики як споживачів, так i постачальників компонентів виробництва продукції внаслідок нестабільної якості;

- відсутність загальноприйнятого підходу до оцінювання здатності постачальників компонентів виробництва гарантувати стабільну якість продукції.

Вирішення цих проблем взяла на себе Міжнародна організація по стандартизації (ISO), а саме спеціалісти технічного комітету ISO/TK176 «Менеджмент якості і забезпечення якості». Результати їхньої роботи знайшли своє відображення в міжнародних стандартах ISO, які одержали індекс 9000 (стандарти ISO серії 9000). Розроблені стандарти увібрали в себе все раціональне, що було накопичено в цій сфері знань і практичної діяльності. Викладені в цих стандартах принципи, що були узгоджені між професіоналами в сфері якості, можуть бути використані в діяльності будьякої виробничої або сервісної організації, як державного, так і приватного сектору. Проте ці стандарти, як і вся система стандартизації, мають динамічну ознаку, тобто вони мають доповнюватися і змінюватися з плином розвитку людського суспільства в умовах глобалізації ринків. Узагальнюючи вищесказане можна дійти висновкупро те, що системи менеджменту якості, що побудовані на вимогах означених вище стандартів, також повинні розвиватися в умовах глобалізації ринків. 
Розвиток систем менеджменту якості на промислових підприємствах повинен здійснюватися 3 урахуванням таких характеристик глобального ринку:

1) насиченість ринку товарами - пропозиція на ринку значно перевищує попит, велика кількість товарів одного і того ж функціонального призначення (товарів-замінників);

2) поінформованість споживача - споживач, як правило, чітко усвідомлює,чого він хоче, і тому є з чого обирати;

3) мінливість (динаміка) ринку - динаміка науково-технічного прогресу, швидкий розвиток високих технологій, одночасна присутність на ринку багатьох конкурентів призводить до постійних змін у пропозиції та попиті.

Наведені характеристики глобального ринку фактично зумовлюють критерії конкурентоспроможності всіх без винятку товарів (робіт, послуг). 3 точки зору провідних вітчизняних та зарубіжних спеціалістів у сфері якості можна виділити чотири основні критерії конкурентоспроможності, які сьогодні відіграють вирішальну роль під час вибору товару.

1) Якість продукції. Якістю продукції в сучасному розумінні $\epsilon$ перш за все економічною категорією, а не філософською чи технічною, як було прийнято трактувати це раніше. На нашу думку найточніше сформульоване визначення цього поняття Свропейською організацією 3 контролю якості: «Продукція вважається хорошої якості, якщо за мінімальних витрат протягом усього її життєвого циклу вона максимально сприяє здоров'ю і щастю людей, які залучені до іiі проектування і відновлення (повторного використання) за умови мінімальних витрат енергії та інших ресурсів i за допустимій (прийнятній дії на навколишнє середовище і суспільство)" [5]. Таке формулювання чітко визначає зв'язок проблеми якості продукції з іншими життєво важливими для людини глобальними проблемами: обмеженість природних ресурсів, раціональне використання природних ресурсів, збереження навколишнього середовища, вплив результатів господарської діяльності на умови життя сучасного покоління людей та їх нащадків. На якість продукції в умовах глобалізації ринків впливає значна кількість факторів, що діють, як самостійно, так і у взаємозв'язку між собою. Ці фактори можна об’єднати в такі групи: економічні, технічні, організаційні. 3 нашої точки зору, незважаючи на важливість та актуальність усіхбез винятку перелічених факторів, основна увага повинна бути приділена саме економічним факторам впливу на якість промислової продукції. Економічні фактори (ціна, собівартість, системи та форми оплати праці, рівень оплати, рівень витрат на технічне обслуговування і ремонт) особливо важливі в ринковій економіці, тому що їм одночасно властиві контрольно-аналітичні і стимулюючі властивості.

2) Собівартість та ціна товару. За ринкових умов господарювання ціна $\epsilon$ ключовим економічним важелем, що впливає на конкурентоспроможність промислової продукції. За інших однакових умов конкурентоспроможність тим вища, чим більше можливостей в організації 
знижувати ціну товару. Проте ці можливості залежать від реальних витрат на створення продукції і доставки іï на ринок до споживача. Таким чином, в умовах глобалізації першочерговим завданням підприємств $є$ зниження готових витрат (повної собівартості) виготовленої продукції (робіт, послуг). Складовою повної собівартості промислової продукції є витрати на якість. Як свідчить набутий досвід, переважна більшість вітчизняних промислових підприємств не приділяє належної уваги питанням обліку витрат на якість. Уноменклатурі калькуляційних статей витрат для більшості промислових підприємств різних галузей відсутня цільова стаття витрат на якість. У кращому випадку на деяких підприємствах під час обчисленняосновних статей калькуляції застосовується стаття «Утрати від браку». Отже, сучасна концепція розвитку систем менеджменту якості тісно пов’язана 3 управлінням витратами на якість. У свою чергу управління витратами на якість пов’язане з їх раціональною класифікацією, що потребує подальших науковихдосліджень

3) Витрати в процесі експлуатації продукції. Переважна більшість споживачів зважають на сумарні витрати, які пов'язані не тільки 3 виготовленням продукції, а також з подальшою іï експлуатацією (витрати на утримання, ремонт тощо). За інших однакових умов переваги має продукція за нижчою вартістю експлуатації. Витрати в процесі експлуатації у поєднанні 3 витратами під час виготовлення та реалізації продукції характеризує комплексний показник якості продукції (інтегральний показник). Він відображає відношення сумарного корисного ефекту від експлуатації або споживання продукції до сумарних витрат на іiі створення i експлуатації (споживання).

4) Імідж виробника. Імідж виробника продукції виступає як додатковий фактор до перерахованих вище, проте часто він $є$ інтегральним фактором конкурентоспроможності продукції. Імідж виробника формується у результаті тривалої та бездоганної роботи на ринку. Одним із способів завоювання довіри споживачів є процеси сертифікації продукції або систем менеджменту якості виробників авторитетними акредитованими органами 3 сертифікації. Перші шість керівних нормативних документів державної системи сертифікації УкрСЕПРО були розроблені ще у далекому 1993 році Українським науково-виробничим центром стандартизації, метрології i сертифікації та введені в дію Наказом Держстандарту України №94 від 30.06.1993p. На їх основі у 1996 році було розроблено 11 державних стандартів України (ДСТУ) системи УкрСЕПРО, які разом 3 іншими нормативними документами становлять діючу базу вітчизняної системи сертифікації.

3 наведених вище критеріїв конкурентоспроможності три перших (якість, собівартість та ціна витрат в процесі експлуатації продукції) 3 нашої точки зору, є найбільш вагомими. При цьому якість продукції серед цих критеріїв має найважливіший пріоритет.

Стратегія, в якій пріоритет віддається якості, це стратегія, що розрахована на тривале та стале положення підприємства на глобальному 
ринку. Таким чином, в умовах глобального ринку для підприємств, що прагнуть сталого положення на ринку, необхідний менеджмент, який забезпечує переваги над конкурентами в питаннях якості, собівартості, ціни. При цьому схильність ринку до постійних змін вимагає аби система якості підприємства була гнучкою i мала властивість змінюватися та пристосовуватися до змін ринку.

Постійне вдосконалення процесів на підприємстві в системі менеджменту якості на вітчизняних підприємствах передбачає виконання комплексу робіт (рис. 1).

Аналіз причин, що впливають на якість

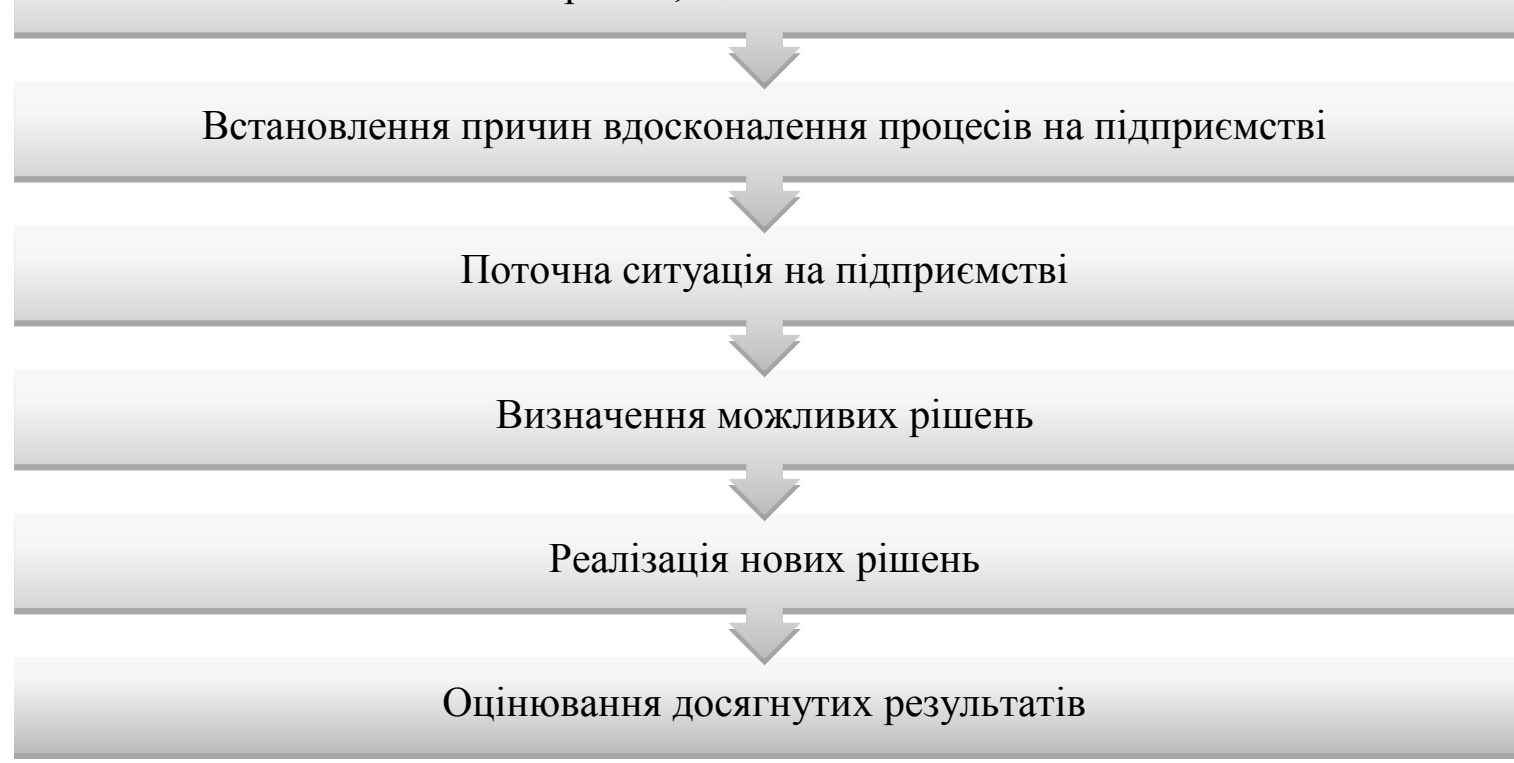

Рисунок 1 - Комплекс робіт постійного удосконалення процесів в системі менеджменту якості підприємства

Джерело: складено авторами

Міжнародні стандарти ISO серії 9000, які в Україні отримали статус національних, містять мінімальні вимоги, яким має відповідати система якості на підприємстві, тому на їх базі можуть розроблятися i використовуватись й інші системи, що враховують специфіку окремих галузей промисловості.

3 нашої точки зору в умовах сьогодення для вітчизняних промислових підприємств найбільш прийнятною для використання $\epsilon$ удосконалення діючих систем менеджменту якості на базі концепції TQM (Total Quality Management). Українською мовою я концепція має назву « загальне (всеохоплююче, тотальне) управління якістю» або «загальний менеджмент якістю».

Сучасна концепція TQM склалася на початку 1980-х років під впливом ідей Е. Демінга, Дж. Джурана, К. Ісікави, А. Фейгенбаума. Найбільше поширення концепція ТQM отримала в таких промислово розвинутих країнах як США, Велика Британія, Японія, Південна Корея, Тайвань. 
Незважаючи на єдність ідеології концепція TQM в різних країнах мала свої національні особливості, виходячи з особливостей iï національного розвитку та робіт з менеджменту якості.

Для вітчизняних промислових підприємств удосконалення діючих систем менеджменту якості доцільно здійснювати з дотриманням наступних фундаментальних принципів.

1) Орієнтація підприємства виключно на вимоги потенційних споживачів. Пам'ятати, що успіх підприємства в умовах ринкової економіки залежить в першу чергу від задоволення вимог та сподівань саме споживачів

2) Безперервне удосконалення всіх без винятку виробничих (основних, допоміжних, обслуговуючих) процесів та процесів управління

3) Участь усього без винятку персоналу у вирішенні проблем якості. Тут варто зазначити про досвід роботи «гуртків якості», що зародився в Японії у 1962 році з ініціативи К. Ісікави, видатного спеціаліста у сфері якості. Японські «гуртки якості» ставлять за мету підвищення якості продукції через удосконалення процесу виробництва. Підвищення продуктивності праці розглядається як результат цих процесів. В колишньому Радянському Союзі гуртки якості почали функціонувати з 1986p як громадські формування робітників, інженерно- технічних працівників та службовців. Вони створювались на добровільних засадах на дільницях, в цехах, відділах та ін. підрозділах підприємства [6]. Але в силу різних об'єктивних та суб'єктивних причин вони не одержала широкого розповсюдження , а 3 розпадом Союзу практично припинили свою діяльність.

4) Безперервне підвищення кваліфікації працівників не тільки у сфері якості, а також в інших напрямах діяльності підприємства (економічна, комерційна, зовнішньоекономічна, соціальна та інші види діяльності)

5) Основна увага повинна бути приділена не на виявлення, а на попередження дефектів продукції. За даними американських експертів, виявлення браку на стадії складання радіоелектронних виробів побутового призначення принесе підприємству збиток у розмірі декілька доларів, а схоже виявлення браку споживачами тягне за собою збиток у розмірі декількох сотень доларів.

6) Ставлення до забезпечення i підвищення якості як до безперервного процесу. Варто пам'ятати, що якість готової продукції $\epsilon$ наслідком досягнення якості на всіх попередніх етапах виробничого процесу. Показовим прикладом є так звана «Спіраль Джурана - концептуальна модель дотримання поліпшення якості виробів, починаючи з робіт по дослідженню ринку, розроблення проектного завдання, розроблення технологічних процесів, матеріально-технічного забезпечення виробництва та закінчуючи збутом, сервісним обслуговуванням і утилізацією продукції.

Сформульовані принципи визначають ідейний зміст філософії TQM, що трактує якість як основний критерій оцінювання роботи підприємства, у іiі широкому економічному і соціально-психологічному розумінні, руйнує тезу про неминучість протиріччя між виробником та споживачами. 
Концепція TQM є універсальною в тому розумінні, що вона отримала позитивний досвід впровадження не тільки на промислових підприємствах, а також і в інших сферах людської діяльності: для роботи органів державної влади, медичної галузі, вищої школи, сфери обслуговування тощо. Тому дослідження удосконалення систем менеджменту якості на базі концепції TQM в цих галузях є доцільними в перспективі.

Концепцію удосконалення систем менеджменту якості на вітчизняних промислових підприємствах можна реалізувати завдяки використанню певного набору методів і засобів (матеріальних, нематеріальних, людських). На сьогодні у світовій практиці вже накопичений i продовжує поповнюватися арсенал цих методів та засобів. Це дає можливість будьякому промисловому підприємству використовувати їх для впровадження концепції TQM, але з урахуванням специфічних особливостей конкретно обраного підприємства. На нашу думку, найбільш придатними для промислових підприємств є така сукупність методів та засобів:

1) Впроваджувати в практику роботи підприємств циклічну модель управління якістю PDCA (цикл управління У. Шухарта). Сутність цієї моделі полягає в тому, що розширивши характеристику управління, запропоновану Тейлором (планування - реалізація - перевірка), У. Шухарт запропонував циклічну модель, яка розподіляє управління на чотири основні стадії: планування (Plan), реалізація (Do), перевірка (Check) i коригуюча дія (Action). Мету Шухарта, який у повсякденному вжитку одержав назву «Цикл Демінга» особливо розповсюдився в Японії, де був доповнений стадіями цілепокладання та навчання кадрів японськими спеціалістами (рис. 2)

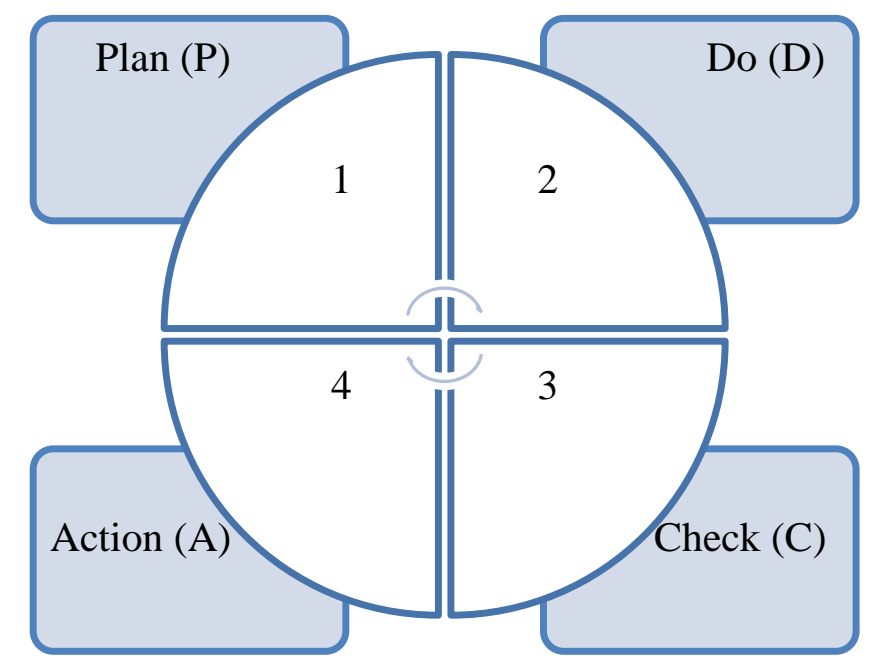

Рисунок 2 - Циклічна модель управління якістю PDCA Джерело: [5]

2) Впроваджувати статистичні методи контролю якості та регулювання технологічних процесів . До них належать: діаграми Парето, причинно-наслідкові діаграми I. Кауру, контрольні карти У. Шухарта, гістограми. В цілому при їх застосуванні можна створити на кожному промисловому підприємстві ефективну систему методів контролю й аналізу 
якості. Особливо високу результативність та ефективність ці методи продемонстрували в умовах велико серійного та масового типів виробництв. Ці методи можна використовувати у будь-якій послідовності, в різних ситуаціях, їх можна розглядати і як цілісну систему, і як окремі інструменти аналізу. На довершення вищесказаному, ці методи не потребують значних матеріальних ресурсів

3) Впроваджувати концепцію «точно в строк». В англійському перекладі ця концепція відома під назвою «Just in time»[7]. Концепція була розроблена в 1960-х роках в японській суднобудівній промисловості. Ї̈ї сутність полягає втому, що необхідно виробляти та постачати готові вироби до моменту їх реалізації, складальні вузли (одиниці) - до моменту початку складання вузлів, сировинні ресурси та матеріали - до моменту виготовлення окремих деталей. В Японії цей спосіб високоефективного виробництва, як це було доведено практикою, називають також «з ложки прямо в рот», коли виробничі запаси і обсяги готової продукції на складах підприємства практично наближається до нульового рівня. Така організація виробництва також сприяє оперативному виявленню бракованих деталей: брак виключається докорінно. Звичайно слід зазначити, що впровадження такої концепції на вітчизняних промислових підприємствах пов'язане з значними зусиллями 3 точки зору забезпечення належної виробничої дисципліни на підприємстві, організації поставок продукції споживачам тощо.

4) Маркетингова функція якості. Виконання цієї функції передбачає широке впровадження економіко-математичних методів, які повинні в системі менеджменту якості вирішувати такі завдання:

- нормування вимог до якості продукції;

- вияснення точки зору споживачів щодо ціни та якості продукції;

- встановлення показників надійності продукції (безвідмовність, довговічність, ремонтопридатність, транспортабельність);

- оцінювання технічного рівня якості продукції у порівнянні з аналогічною продукцією потенційних конкурентів;

- аналіз витрат споживачів під час використання (експлуатації) продукції.

5) Бенчмаркінг ( англ. benchmarking - опорна точка). Ця функція полягає у пошуках практики роботи у промисловості, яка сприяє досягненню відмінних результатів діяльності конкретно обраного підприємства у порівнянні зі спорідненими підприємствами-конкурентами. Зміст бенчмаркінгу пов'язаний $з$ діями підприємства в порівняльному оцінюванні свого стану в тому випадку, коли проявляється потреба в змінах. Мета бенчмаркінгу - на основі зіставлення підприємства з більш успішно діючими підприємствами (не обов'язково з конкурентами) визначення власних шляхів розвитку та можливосте для удосконалення. Бажано застосовувати у пошуках кращої практики всі три види бенчмаркінгу, а саме: внутрішній, зовнішній та функціональний. Процес бенчмаркінгу повинен передбачати виконання таких робіт:

- встановлення об'єктів для порівняння; 
- вибір підприємств для порівняння;

- збір та аналіз отриманих даних;

- виявлення фактичного рівня відставання від кращої практики (підприємств)

- розроблення плану (програми) першочергових дій

- реалізація плану бенчмаркінгу й оцінювання його результатів

Висновки. Ефективне управління якістю, яке забезпечує високий рівень задоволення потреб та очікувань споживачів, $\epsilon$ важливою передумовою успіху будь-якого підприємства, незважаючи на вид діяльності або ж форму власності. Але не лише якість продукції та послуг $є$ основним інструментом конкуренції між підприємствами. В умовах глобалізації ринку підприємства конкурують з урахуванням ефективності та результативності систем менеджменту якості, які потрібно постійно вдосконалювати. Відомий американський вчений в питаннях якості А. Фейгенбаум говорив: «Не існує такого поняття, як постійний рівень якості (не може бути константою). Постійне підвищення якості - це спосіб існування фірми»

До елементів наукової новизни проведеного дослідження належать такі положення, запропоновані авторами, а саме:

1) сформульовано головні напрямки розвитку систем менеджменту якості на вітчизняних підприємствах, який повинен здійснюватися безперервно 3 урахуванням таких характеристик глобальних ринків, як насиченість ринків товарами, широка інформованість покупців стосовно характеристик товарів (робіт, послуг), високі темпи мінливості (динаміки) ринків;

2) визначено головні критерії конкурентоспроможності продукції підприємств, які необхідно першочергово враховувати при вдосконаленні діючих на підприємстві систем менеджменту якості. Ці критерії відіграють вирішальну роль під час вибору товару покупцями, а саме: якість, яка в сучасному розумінні є перш за все економічною категорією; собівартість та ціна, що $\epsilon$ ключовим економічним важелем, який впливає на конкурентоспроможність продукції; витрати в процесі експлуатації продукції, оскільки переважна більшість споживачів зважають на сумарні витрати, що пов'язані не тільки з виготовленням продукції, а й 3 подальшою iii експлуатацією; зручність сервісу з боку виробника(продавця) продукції та їх імідж, як додаткові, але дуже важливі критерії успіху підприємства;

3) розроблено алгоритм комплексу робіт постійного удосконалення в системі менеджменту якості підприємств, який передбачає виконання ряду послідовних етапів, починаючи від встановлення причин вдосконалення процесів та закінчуючи оцінюванням досягнутих підприємством результатів від вдосконалення систем менеджменту якості;

4) доведено, що для вітчизняних промислових підприємств удосконалення діючих систем менеджменту якості доцільно здійснювати 3 дотриманням таких фундаментальних принципів, а саме: орієнтація 
підприємств виключно на вимоги потенційних споживачів; удосконалення на постійній основі всіх без винятку процесів (виробничих, управлінських); залучення всіх без винятку працівників підприємства для вирішення проблем якості, які мають місце на підприємстві.

Сформульовані вище принципи визначають ідейний зміст концепції Total Quality Management (TQM), яка є всебічно перевіреною в практичній діяльності успішно діючих підприємств в умовах глобалізації.

Практичне значення отриманих результатів полягає в наданні рекомендацій щодо вдосконалення діючих на вітчизняних промислових підприємствах систем менеджменту якості, що побудовані на умовах міжнародних стандартів ISO серії 9000. Окрім того, отримані результати дослідження можна використовувати при розробленні нових положень або ж доповненні діючих міжнародних стандартів ISO серії 9000, які в Україні прийняті в якості національних.

Подальші дослідження 3 даного питання доцільно було б присвятити удосконаленню менеджменту якості на основі філософії TQМ у сфері освіти, медицини, обслуговування населення.

\section{Література:}

1. ДСТУ 3410-96. Система сертифікації УкрСЕПРО. Основні положення

2. Васильєв В. Удосконалення діючої системи якості. Стандартизація, сертифікація, якість. 1998. №12. 66 с.

3. Исикава К. Японские методы управления качеством. М.: Экономика, 1988. 215 с.

4. Орлов П. А. Менеджмент качества и сертификация продукции. Учебное пособие. Харьков. ИД «ИНЖЕК». 2004. 303 с.

5. Шаповал М.І. Менеджмент якості. Підручник. К.:Знання, 2003. 471 с.

6. Саранча Г.А. Метрологія, стандартизація, відповідність, акредитація та управління якістю : [підручник] / Г.А. Саранча. КНУБК. К. : Центр навчальної літератури. 2006. $668 \mathrm{c}$.

7. Капінос Г. І. Операційний менеджмент: [підручник] / Г. І. Капінос, І. В. Бабій. К.: Центр навчальної літератури. 2013. 352 с.

8. Операційний менеджмент : навчальний посібник/ В. Г. Воронкова, А. Г. Беліченко та ін. Львів: «Магнолія2006». 2009. 438 с. 